\title{
WHEN HOMER QUOTES CALLIMACHUS: ALLUSIVE POETICS IN THE PROEM OF THE POSTHOMERICA*
}

In Book 12 of Quintus Smyrnaeus' Posthomerica (c. third century C.E.), ${ }^{1}$ the epic poet prepares to list the heroes who entered the Wooden Horse before the sack of Troy. Before he begins, he breaks off to ask for help (Quint. Smyrn. 12.306-13):

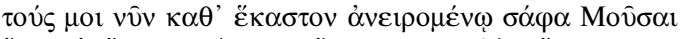

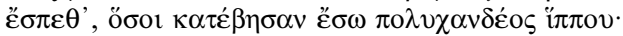

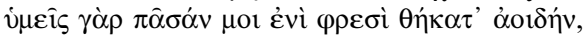

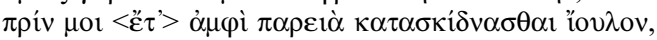

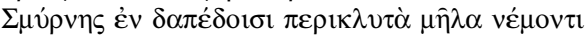

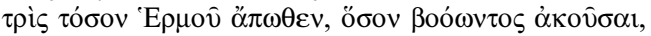

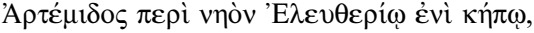

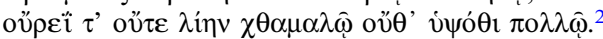

Muses, I ask you to tell me precisely, one by one, the names of all who went inside the cavernous horse. For you were the ones who filled my mind with all song even before down was spread across my cheeks, when I was tending my renowned sheep in the land of Smyrna, three times as far as the shouting distance from the Hermus, near Artemis' temple in the garden of Liberty, on a hill that is neither excessively high nor too low.

The programmatic significance of the passage is first suggested by its position in the poem's architecture. Crowned by Conte as 'proems in the middle', such embedded invocations offer a specific declaration of poetics, dealing with the programmatic as opposed to the thematic, the quale instead of the quid. ${ }^{3}$ Recent treatments of

\footnotetext{
* An earlier version of this article was presented at a workshop on the Posthomerica organized by the Imperial Greek Epic project at the University of Cambridge in April 2016. I thank Leyla Ozbek and Tim Whitmarsh for organizing that event with me, and the participants for their valuable comments. The piece also benefitted from the remarks of this journal's anonymous reviewer. I owe particular thanks to Calum Maciver for his continued enthusiasm for the argument and incisive advice on many aspects of it along the way.

${ }^{1}$ On that date and its controversies, see the most up-to-date treatment in M. Baumbach and S. Bär, 'An introduction to Quintus Smyrnaeus' Posthomerica', in M. Baumbach and S. Bär (edd.), Quintus Smyrnaeus: Transforming Homer in Second Sophistic Epic (Berlin, 2007), 1-26, at 1-8.

${ }^{2}$ The text of Quintus throughout is that of F. Vian (ed.), La Suite d'Homère (Paris, 1963 [vol. 1], 1966 [vol. 2], 1969 [vol. 3]); of the Iliad that of A. Murray, revised by W. Wyatt, Homer Iliad 1-12 (vol. 1) and 13-24 (vol. 2) (Cambridge, Mass. and London, 1999²); of the Odyssey that of A. Murray, revised by G. Dimock, Homer Odyssey 1-12 (vol. 1) and 13-24 (vol. 2) (Cambridge, Mass. and London, 1998 ${ }^{3}$ ); of Callimachus' Aetia that of A. Harder (ed.), Callimachus' Aetia: Introduction, Text and Translation (vol. 1) and Commentary (vol. 2) (Oxford, 2012). Translations of Quintus are adapted from A. James (ed.), Quintus of Smyrna, The Trojan Epic (Baltimore and London, 2004), of Homer from Murray and of Callimachus from Harder.

${ }^{3}$ G. Conte, 'Proems in the middle', in F. Dunn and T. Cole (edd.), Beginnings in Classical Literature (Cambridge, 1992), 147-59.
} 
Quintus' proem have found this declaration in its intertextual patterning. ${ }^{4}$ As well as echoing the Iliadic address before the catalogue of ships (Il. 2.484-92), Quintus' image of the inspired poet tending sheep recalls the invocation of Hesiod's Theogony (22-8). A further reference affects this relationship with the Homeric and the Hesiodic proems: the allusion to the Somnium of the Aetia, where Callimachus re-presents Hesiod's meeting with the Muses (fr. 2.1-2): ${ }^{5}$

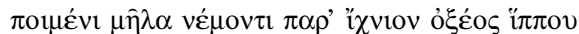

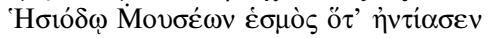

When a swarm of Muses met the shepherd Hesiod who was tending his sheep by the footprint of the quick horse

Whilst never naming any poets, ${ }^{6}$ by alluding to the figures of Homer, Hesiod and Callimachus, Quintus finds a coded way to chart his literary inheritance: introducing a catalogue of heroes, he also catalogues the names of his predecessors, or several identities of himself. The proem thus emerges as a programmatic template for the allusive poetics of the poem; each reference functions as part of a well-directed emulative discourse on the nature and function of its imitation.

This discourse, however, as it is currently understood, focusses on Quintus' integration of Alexandrian poetics into a predominantly Homeric-Hesiodic framework. The presence of Callimachus, it is argued, points to the Alexandrian influences (here Callimachean aesthetics) in the poem, signalling the poet's aim to enrich his traditional epic by including Alexandrian intricacies among the generic Homeric elements. ${ }^{7}$ This article will put forward a different interpretation. Rather than demonstrating Alexandrian indebtedness, I shall argue that Quintus signals with his in-proem a provocative redeployment of Callimachean aesthetics. Taking as its starting point a fundamental paradox of the Posthomerica - that Quintus both implicitly claims Homeric identity and engages with Alexandrian poetics - the main section of this piece will consider the invocation of Book 12 as a self-conscious commentary on this clashing use of models. By analysing the proem's more systematic engagement with Callimachus' poetic programme I shall demonstrate that Quintus co-opts symbolic imagery from the Aetia to make a highly anti-Callimachean point about poetic assimilation and integration. Alexandrian techniques are mobilized to defend a non-Alexandrian poem, and Callimachean tropes are transformed into markers of the Homeric.

\footnotetext{
${ }^{4}$ The most in-depth treatment of the proem's metapoetics is S. Bär, 'Quintus Smyrnaeus und die Tradition des epischen Musenanrufs', in M. Baumbach and S. Bär (edd.), Quintus Smyrnaeus: Transforming Homer in Second Sophistic Epic (Berlin, 2007), 29-64. See also C. Maciver, Quintus Smyrnaeus' Posthomerica: Engaging Homer in Late Antiquity (Leiden, 2012), 33-8, and B. Boyten, 'Epic journeys: studies in the reception of the hero and heroism in Quintus Smyrnaeus' Posthomerica' (Diss., University College London, 2010), 276-81.

${ }^{5}$ These models have long been noted: cf. Vian (n. 2), 101; M. Campbell, A Commentary on Quintus Smyrnaeus Posthomerica XII (Leiden, 1981), 100-5; U. Gärtner, Quintus Smyrnaeus und die Aeneis: Zur Nachwirkung Virgils in der griechischen Literatur der Kaiserzeit (Munich, 2005), 23; and Bär (n. 4), 40-52.

${ }^{6}$ Quintus never names poets. Imperial Greek poets tend not to, unlike late antique Latin poets. See the discussion in C. Maciver, 'Nonnus and Imperial Greek poetry', in D. Accorinti (ed.), Brill's Companion to Nonnus of Panopolis (Leiden, 2016), 529-48, at 530.

${ }^{7}$ For this view, see Bär (n. 4), 47-51; Maciver (n. 4), 33-8; and C. Maciver, 'Representative bees in Quintus Smyrnaeus' Posthomerica', CPh 107 (2012), 53-69, at 64-8. These are currently the most influential readings of the passage.
} 


\section{CLASSIFYING QUINTUS}

The epigrammist Pollianus (first/second century C.E.) provides a scathing synthesis of the sorts of charges which could be levied against the imitation of traditional epic by Imperial poets. Disparaging Homerizing narrative epic as derivative and mundane, he enrols himself in the freer tradition of elegy, and expresses his critique in distinctly Callimachean terms (Anth. Pal. 11.130):

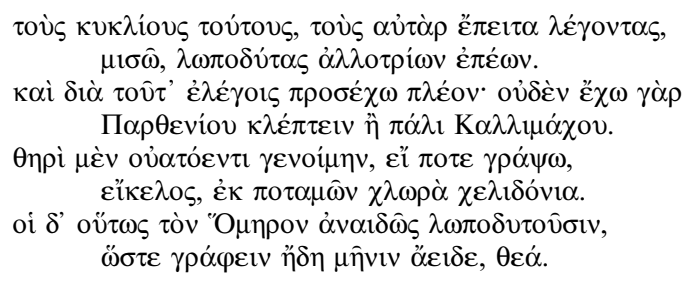

I hate these cyclic poets who say 'but nonetheless', plunderers of the verses of others, and so I pay more attention to elegies, for there is nothing I want to steal from Callimachus or Parthenius. Let me become like an 'eared beast' if ever I write 'from the rivers yellow king-cup.' But these epic poets plunder Homer so shamelessly that they already write 'Sing, O Goddess, the wrath. ${ }^{8}$

Surviving evidence from the first three centuries C.E. suggests that Pollianus was swimming with the tide: Greek hexameter poets seem mainly to have followed, and fewer to have flouted, Callimachean precepts. ${ }^{9}$

Those who did take on Trojan themes and adopt the Homeric style went to great efforts to dissociate their works with notions of mindless plundering. Triphiodorus, for example, has been read as making his epyllion ${ }^{10}$ on the sack of Troy sound Homeric without being accused of parroting through an aversion to borrowing more than half a line from the Iliad or the Odyssey and by displaying his interest in lexical innovation. ${ }^{11}$ Nonnus' sprawling Dionysiaca obsessively thematizes rebellion, filiation and (dis)continuity in relation to Homer, appropriating and transforming Homeric style, scenes and $\operatorname{skin}^{12}$ for its new polymorphic poetics. ${ }^{13}$ This appropriation is sealed in Nonnus' own proem in the late middle (Dion. 25.1-270), which-exceptionally-

\footnotetext{
${ }^{8}$ Trans. from the fourth volume of W. Paton (ed.), The Greek Anthology (London, 1918).

${ }^{9}$ See E. Bowie, 'Poetry and poets in Asia and Achaia', in S. Walker and Averil Cameron (edd.), The Greek Renaissance in the Roman Empire (Bulletin Supplement 55) (London, 1989), 198-205.

${ }^{10}$ On this poetic type in antiquity, see S. Bär and M. Baumbach (edd.), Brill's Companion to Greek and Latin Epyllion and its Reception (Leiden, 2012); M. Fernandelli, Catullo e la rinascita dell'epos: dal carme 64 all'Eneide (Hildesheim-Zürich-New York, 2012); and the papers in Aitia 6 Recherches sur l'epyllion à l'époque hellénistique et au-delà (2016 [online]).

${ }^{11}$ See especially L. Miguélez-Cavero (ed.), Triphiodorus, The Sack of Troy: A General Study and a Commentary (Berlin, 2013), 38-87.

${ }^{12}$ Nonnus in his preface asks the Mimallons to leave the rancid seal-skins to Homer for Menelaus (Dion. 1.34-8).

${ }^{13}$ It is a characteristically Nonnian paradox that the very word used in the opening proem to symbolize this poetics is itself emblematically Homeric in origin: the Odyssean $\pi \mathrm{o} \lambda \dot{\tau} \tau \rho \circ \pi \mathrm{s}$, hijacked at Dion. 1.14. On Nonnus' attitude to Homer, N. Hopkinson, 'Nonnus and Homer', in N. Hopkinson (ed.), Studies in the Dionysiaca of Nonnus (Cambridge, 1994), 9-42 remains indispensable. See also H. Bannert and N. Kröll, 'Nonnus and the Homeric poems', in D. Accorinti (ed.), Brill's Companion to Nonnus of Panopolis (Leiden, 2016), 481-507. For Nonnus' metapoetics, see R. Shorrock, The Challenge of Epic: Allusive Engagement in the Dionysiaca of Nonnus (Leiden, 2001).
} 
declares explicitly its stance towards 'father Homer' (Dion. 25.265), whom the poet names, reveres and rivals in one poetic declaration. ${ }^{14}$ As Pollianus' sentiments make clear, despite the continuing modern debates about the level of 'anti-epic' sentiment in Callimachus' poetic programme, ${ }^{15}$ in terms of reception rather than conception his stylistic proclamations could be engaged with as critiques of the writing of traditional epic poetry, forming the implicit (and sometimes explicit) backdrop to charges of bland imitation and their responses.

In terms of discerning Quintus' engagement with these principles, a problem arises in the lack of categorization. Compared to the fundamentally Alexandrian epic of Apollonius, and Nonnus' multifarious redrafting, the Posthomerica's compatibility with the various (and varied) components of Alexandrian aesthetics is difficult to pin down. ${ }^{16}$ At fourteen books, the poem could fall into the category of $\tau$ ò $\mu \varepsilon \dot{\gamma} \alpha \beta$ i $\beta \lambda$ íov against which Callimachus railed, and its subject matter could also be described as

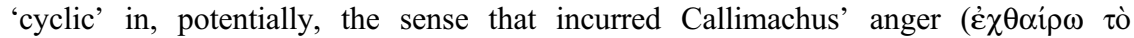

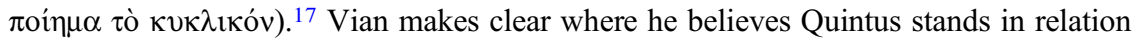
to Callimachus: in his reading, Quintus has no taste for the learned poetics of the Callimachean school, and his conception of epic is exactly what Callimachus fought against. ${ }^{18}$

Recent work, however, has begun to question this conclusion, drawing attention to a number of Alexandrian aspects of the poem: references to Hellenistic authors, selfconscious techniques of allusion, and learned intertextual intricacies. ${ }^{19}$ One such aspect receiving increasing attention is the Posthomerica's sophisticated reconfiguration of Homeric language. ${ }^{20}$ Studies have revealed Quintus' tendency to variegate Homeric

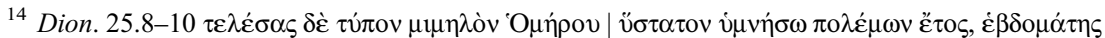

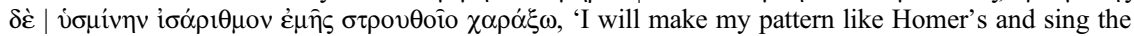
last year of warfare, I will describe that which has the number of my seventh sparrow'; and Dion.

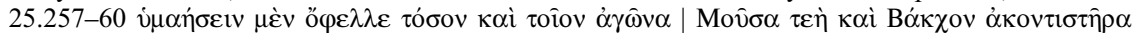

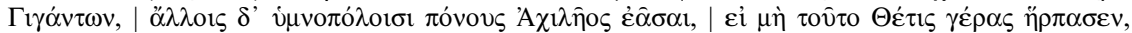
'your Muse ought to have hymned so great and mighty a struggle, how Bacchus brought low the Giants, and ought to have left the labours of Achilles to other bards, had not Thetis stolen that glory from you.' Cf. also the depiction of Homer as the author of the 'lying book' at Dion. 42.181.

${ }^{15}$ Among the most strident arguments against an anti-epic agenda remain those of G. Hutchinson, Hellenistic Poetry (Oxford, 1988) and Alan Cameron, Callimachus and His Critics (Princeton, 1995). Relevant discussion for the Posthomerica in Maciver (n. 7), 67.

${ }^{16}$ For these two epics as useful poles of comparison for Quintus in chronological terms at least, and on the problems of defining an Imperial Greek poetic 'aesthetic' more broadly, see Maciver (n. 7), 678 , to whose lucid comments this paragraph is particularly indebted. On Nonnus and Alexandrianism, see A. Lasek, 'Nonnus and the play of genres', in D. Accorinti (ed.), Brill's Companion to Nonnus of Panopolis (Leiden, 2016), 402-22, and B. Acosta-Hughes, 'Composing the masters: an essay on Nonnus and Hellenistic poetry', in D. Accorinti (ed.), Brill's Companion to Nonnus of Panopolis (Leiden, 2016), 507-28.

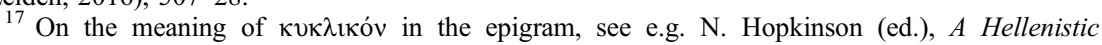
Anthology (Cambridge, 1998), 86; S. Goldhill, The Poet's Voice: Essays on Poetics and Greek Literature (Cambridge, 1991), 223-34; and Cameron (n. 15), 387-402.

${ }^{18}$ Vian (n. 2), xl.

${ }^{19}$ Vian himself suggests many Hellenistic models and sources for the poem: see F. Vian, Recherches sur les "Posthomerica" de Quintus de Smyrne (Paris, 1959), 101-10. See also Maciver (n. 7) on the use of Apollonian material in Quintus' similes.

${ }^{20}$ This linguistic innovation is in contrast to Quintus' metrical system, which is conservative and largely avoids irregularities: he is not among the later epic poets who show significantly the influence of Callimachus' metrical reforms. See A. Köchly, Quinti Smyrnaei Posthomericum XIV (Leiden, 1850); Vian (n. 19), 212-49; and A. James and K. Lee (edd.), A Commentary on Quintus of Smyrna, Posthomerica $V$ (Leiden, 2000), 30-1. 
formulae, using Homeric elements but very rarely repeating them exactly; and have emphasized his avoidance of common Homeric adjectives in favour of rare ones. $\pi \mathrm{o} \lambda \hat{v} \tau \lambda \eta \tau \mathrm{s}$, for instance, occurs only once in Homer, but thirteen times in the Posthomerica. $\pi \mathrm{o} \lambda \dot{\tau} \tau \lambda \alpha \varsigma$ occurs forty-two times in Homer, but is avoided altogether by Quintus. ${ }^{21}$ This practice, to take Homeric rarities and fill his poem with them, has generally been identified as Alexandrian, associated with the imitatio cum uariatione and Selbstvariation so prevalent in the philological games of Hellenistic poets. ${ }^{22}$ Through the integration of such features, Quintus is seen to put forward his response to the charge of 'Homeric plundering': augmenting his hyper-Homeric style and subject matter with elements that can be aligned with the allusive techniques and slender Muse of Callimachus.

This line of reading, which pits the poem's Alexandrian influences against its generic Homeric intertextuality, leaves unresolved one of the most fundamental aspects of the work, an aspect which makes it unique among surviving Imperial Greek epic: its implicit claim to Homeric authorship, and, within this guise, the conceit of being the missing middle part of his epic canon-Iliadic sequel, Odyssean prequel. ${ }^{23}$ The direct continuity with the Iliad is announced by the unexpected absence of a Muse invocation at the beginning of Book 1, while the connection to the Odyssey is secured by an increase in Odyssean allusions in the final books of the poem, and a direct intertextual gloss of its opening. ${ }^{24}$ Quintus also repeats defining Homeric set pieces, most strikingly the Shield of Achilles, stressed as being the very same artefact as that in Iliad 19. ${ }^{25}$ This self-positioning as 'still Homer' must affect our interpretation of Quintus' whole intertextual programmatics, the tone in which we take his engagement with any later literary modes. If all intertextuality is paradoxical, in that an author signals the inclusion of a

21 The most significant contribution remains that of W. Appel, Die homerischen Hapax Legomena in den Posthomerica des Quintus Smyrnaeus (Toruń, 1994), who calculated that one in ten of Quintus' words is a Homeric hapax. See also G. Chrysafis, 'Pedantry and elegance in Quintus Smyrnaeus' Posthomerica', Corolla Londiniensis 4 (1985), 17-42; James and Lee (n. 20), 21-30; S. Bär, Quintus Smyrnaeus: "Posthomerica" 1: Die Wiedergeburt des Epos aus dem Geiste der Amazonomachie. Mit einem Kommentar zu den Versen 1-219 (Göttingen, 2009); and, most recently, A. Ferreccio, Commento al libro II dei Posthomerica di Quinto Smirneo (Rome, 2014).

22 On Hellenistic uses of Homeric glosses, see A. Rengakos, Der Homertext und die hellenistischen Dichter (Stuttgart, 1993).

${ }^{23}$ This pretence of Homeric authorship is what sets the Posthomerica apart from other 'inter-Homeric' works in the ancient tradition, for instance the Aethiopis, which also began directly at the end of the Iliad, and led to an alternative final line for the Iliad (Aethiopis fr. 1 W.: $\ddot{\zeta}$ oi $\gamma$ '

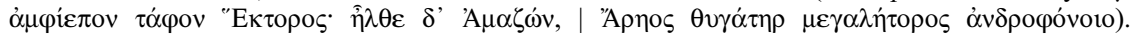
However, the cyclic poems, in so far as we can tell, make no discrete claims to Homeric identity of their own. See M. Davis, The Greek Epic Cycle (Bristol, 1989); M. West, The Epic Cycle: A Commentary on the Lost Trojan Epics (Oxford, 2013); M. Fantuzzi and C. Tsagalis (edd.), The Greek Epic Cycle and its Ancient Reception: A Companion (Cambridge, 2015); and, particularly, J. Burgess, The Tradition of the Trojan War in Homer and the Epic Cycle (Baltimore and London, 2001). On Quintus' thorny relationship to these poems, see Maciver (n. 4), 8-9, Baumbach and Bär (n. 1), 1, and M. Baumbach, 'The epic cycle and Imperial Greek epic', in M. Fantuzzi and C. Tsagalis (edd.), The Greek Epic Cycle and its Ancient Reception: A Companion (Cambridge, 2015), 604-22.

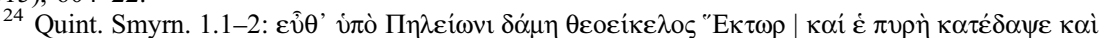

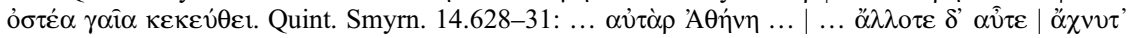

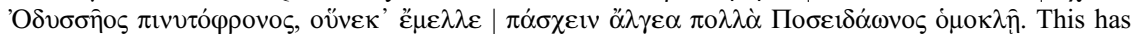
become more or less the established reading of Quintus' poetics, stretching as far back as (at least) Köchly (n. 20). The bibliography is now quite large on this point: further reading in Bär (n. 21), 69-78 and Maciver (n. 4), 7-38.

${ }^{25}$ Quint. Smyrn. 5.1-101. See Maciver (n. 4), 39-48, quotation at 40. 
literary voice that is within and yet separate from their own, then in Quintus this paradox is all-engulfing, and overwhelming.

The proem of Book 12 represents the most intense locus for this contradictory practice. On the one hand, the passage exhibits multiple 'Alexandrian' characteristics. Its very status as an embedded programmatic proem is a reflection of a mode of self-consciousness derived largely from the Alexandrian poets. ${ }^{26}$ Its literary nexusreferring to multiple sources, requiring a breadth of reading to unlock a culminating incorporation of texts-also suggests an Alexandrian-style intricacy of intertextual play. ${ }^{27}$ And it contains the poem's most explicit 'quotation' of Callimachus, evoking a pre-existing intertextual relationship by alluding to a passage where Callimachus comments on his own place in the chain of literary reception.

Yet, this is also the moment where Quintus comes closest to directly claiming Homeric identity. The mention of Smyrna (310) has long been recognized as an allusion to one of Homer's most celebrated mythological birthplaces. ${ }^{28}$ The surrounding details add further intensity to this Homeric self-indexing. The Hermus (311) was a river closely associated in antiquity with Smyrna. ${ }^{29}$ And the reference to the Temple of Artemis (312) could hint at the link between the goddess Artemis and Homer's birthplace on the river Meles, as is established implicitly in Archaic poetry in the Homeric Hymn to Artemis. ${ }^{30}$ Through such sophisticated touches, Quintus takes facets of Homer's biographical tradition, well known during his contemporary era, and ascribes them to his own poetic voice. ${ }^{31}$ This simultaneous Homeric ventriloquism and Callimachean allusion crystallizes for the reader the problems with placing the two influences side by side. As Bär remarks, the pressing question becomes what it means for Quintus to revert to a model that is so critical of traditional epic poetry. ${ }^{32}$

Harnessing the programmatic potential of the in-proem, Quintus uses his invocation to pose-and answer - this question. In order to access this answer, however, it must be perceived that the interaction with Callimachus goes beyond the near-quotation of a Somnium line. Stephen Hinds, in his seminal work on the art of allusion, writes of a type of literary interplay that he terms 'tendentious annotation', in which poets forfeit direct citation of a source model in favour of more embedded ways of metaphorizing

${ }^{26}$ Conte (n. 3), 157: 'under the terms of the post-Alexandrian code of literary conduct, poets could no longer ignore their self-reflective consciousness. Whilst striving to stay faithful to that ancient essentiality of stating what would be sung, they felt compelled also, in the fashion of the Alexandrians, to suggest how they were going to sing it.'

27 So Maciver (n. 7), 678.

${ }^{28}$ Cf. [Hdt.] Vit. Hom. 19-21; [Plut.] Vit. Hom. 17-20; Anth. Pal. 9.672; 11.422; 16.295-8; 16.320. It was also an important culture centre in the 'Second Sophistic'. Further discussion in Bär (n. 4), $52-5$.

${ }^{29}$ Cf. Il. 20.392 and Hes. Theog. 343. For later references to the river in antique geographical writings, see H. Kaletsch, 'Hermos ('Epuós) [2]', DNP 5 (1998), 452-3.

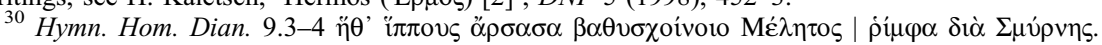
Scholars remain divided about Quintus' choice of Artemis here. For biographical speculation about the temple's physical whereabouts, see Vian (n. 19), 131 and Vian (n. 2), x. Bär (n. 4), 55-9 offers a metapoetic interpretation: that the goddess' occasional association with fertility enables Quintus to intimate that the Wooden Horse is the 'mother of evil', pregnant with soldiers. But Artemis' early connection with Smyrna must surely also affect interpretation of her function in this passage, and has not, to my knowledge, been considered as the explanation for her presence, bar the passing comment in B. Graziosi, Inventing Homer: The Early Reception of Epic (Cambridge, 2002), 77, and Boyten (n. 4), 280.

31 The fact that this allusion to Homeric identity is still cryptic, in that the epic 'I' remains unnamed, is in-keeping with Homer's famous anonymity.

${ }^{32}$ Bär (n. 4), 50. 
their engagement. ${ }^{33}$ This phenomenon can be applied to the proem of the Posthomerica and its relationship with Callimachus, but with an important difference. Quintus evokes, in a covert manner, a range of recognizable tropes from Callimachus' poetry, specifically those pertaining to his poetic programme. ${ }^{34}$ But rather than merely annotating his engagement, he hijacks and subverts this imagery so as to use it against its originating source. This technique - the most tendentious form of tendentious troping-enables the poet to define and defend his Homerizing endeavour using the tools of its most ardent detractor.

\section{ONE CONTINUOUS SONG}

Quintus begins his invocation by asking the Muses for clear and precise information about the identity of each hero, and explains this request by asserting their status as the source of all of his song (12.306-8). The most important phrase here in terms of allusion and self-reflection upon this allusion is $\pi \hat{\alpha} \sigma \alpha \nu \ldots \dot{\alpha}$ ot $\delta \eta \dot{v}$. Various interpretations of this verse have been offered. Ambiguity centres on whether to render $\pi \hat{\alpha} \sigma \alpha v$ as 'all' or

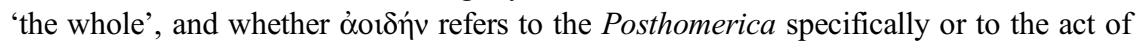
poetic composition in general. It has not been considered that this very ambivalence could have a strong interpretative function - that investing the phrase with two systems of meaning allows the reader to unlock a spectrum of symbolic associations.

One such association is with the idea of 'the whole song', with $\pi \hat{\alpha} \sigma \alpha \nu$ a totalizing adjective describing the size, coherence and completeness of the present poem under composition. Vian's translation reflects this meaning: 'est-ce vous qui avez mis en mon âme tout ce poème'. ${ }^{35}$ This is a perfectly sensible rendering: Quintus uses the singular $\pi \hat{\alpha} \varsigma$ to mean 'the whole' on ten other occasions in his poem, often when describing an area or space, such as the whole river bursting its banks, or the whole of Greece once covered by a flood. ${ }^{36}$ In all references to song in the poem's primary narrative the verb or the noun of singing relates to a specific composition being performed-Nestor's song at the funeral of Achilles, the bards' tune after the sack of Troy, and the Achaeans' victory ode as they return from razing the city. ${ }^{37}$

On the level of tendentious allusion, taken in this sense Quintus' 'whole song' triggers associations with the Aetia's famous and frequently quoted ${ }^{38} \tilde{\varepsilon} \nu$ ö $\varepsilon 1 \sigma \mu \alpha$

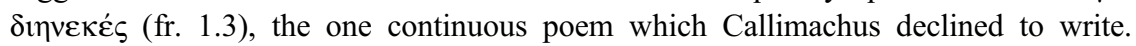
Beyond the $\dot{\alpha} o t \delta \eta^{\prime} / \alpha \varepsilon^{\prime} \sigma \mu \alpha$ similarity, stemming from the same verbal root, the use of

${ }^{33}$ S. Hinds, Allusion and Intertext: Dynamics of Appropriation in Roman Poetry (Cambridge, 1998), 3-16.

${ }^{34}$ This focus on the programmatic sections of Callimachus' euvre-both the stylistic metaphors of the Aetia prologue and other passages which can and have been interpreted symbolically-further suggests that Quintus is indeed engaging with Callimachus as a figure of critique for traditional epic poetry, despite such modern reservations about the suitability of this conception to Callimachus' writings as a whole.

${ }^{35}$ Vian (n. 2), 100.

${ }^{36}$ Quint. Smyrn. 2.641, 3.602, 9.266, 11.125 (the whole ground or plain); 12.97 (the whole of Dardania); 12.181 (the whole of lofty Ida); 13.437 (the whole city); 14.406 (the whole Dardanian coast).

${ }^{37}$ Quint. Smyrn. 4.117-70; 14.121-42 and 14.85-93 respectively. A possible exception is the nightingale's song (Quint. Smyrn. 12.489-96), which could refer to the act of singing in general.

${ }^{38}$ Cf. Cameron (n. 15), 104-32. 
the surprisingly flat verb $\theta \dot{n} \kappa \alpha \tau$ ', where we might expect a stronger notion such as 'breathed' or 'filled', given the inspiratory context, ${ }^{39}$ could nod to the more literal handover of Callimachus' first initiation, when Apollo 'placed the tablet on (his) knees'

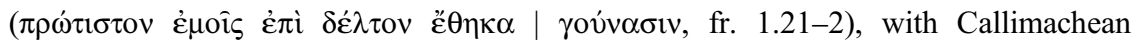
है $\theta \eta \kappa \alpha$ and Quintan $\theta \dot{\eta} \kappa \alpha \tau$ ' in the same metrical sedes.

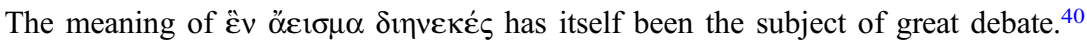
The most relevant potential definitions for our purposes are those which relate specific-

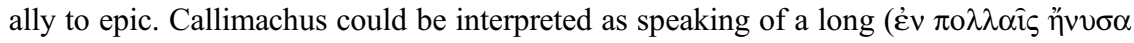
$\chi \imath \lambda \iota \alpha ́ \sigma ı v$, fr. 1.4) continuous narrative, an uninterrupted epic poem, with ह̌v signifying the unity for which Aristotle admired Homer, and Callimachus rejected imitation of him. ${ }^{41}$ It has, however, been pointed out that not all epics do consist of uninterrupted, continuous narrative-most conspicuously the two longest and most famous of them all, the Iliad and the Odyssey. ${ }^{42}$ But, in fact, with Quintus' $\alpha$ or $\delta$, they do. Taken as an

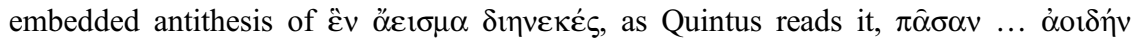
presents a vision of exactly what the Posthomerica is doing; creating one unified narrative which joins the Homeric poems. But the conceit stretches further. Within the frame of the poem's claim to Homeric identity, the $\mu \mathrm{or}$ of this line refers to Homer himself. In the comment that the Muses inspired this poet with one 'entire' song, Quintus thus performs a preposterous restructuring of the original Homeric corpus, ${ }^{43}$ turning it into one continuous poem - moving still further away from Callimachean concepts of disunity and affirming the structural cohesiveness of the Homeric epic narrative by creating it. ${ }^{44}$

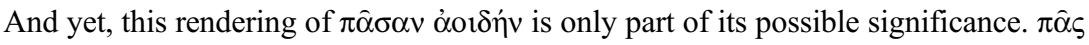
can also, of course, mean 'all' or 'every'; and although singing in the Posthomerica usually has a context-specific application, the particular choice of óotón (the only occurrence of the noun in the poem), in the accusative, at the end of its line, also points to the

39 A useful comparison can perhaps be made with the Vision of Dorotheos, a Greek Christian poem of 360 hexameters by an author who names himself 'the son of Quintus'. Editors have noted similarities in poetic diction with the Posthomerica, including a potential conscious echo of Quint. Smyrn.

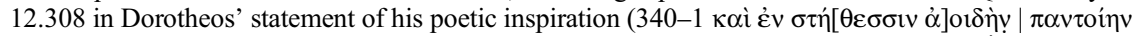

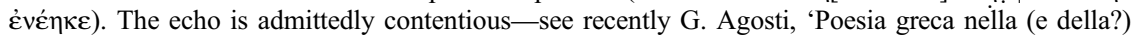
biblioteca Bodmer: aspetti letterari e socioculturali' and A. Camplani, 'Per un profilo storico-religioso degli ambienti di produzione e fruizione dei Papiri Bodmer: contaminazione dei linguaggi e dialettica delle idee nel contesto del dibattito su dualismo e origenismo', in A. Camplani and A. Cacciari (edd.), Adamantius 21 (2015), 86-97 and 98-135 respectively-but remains possible. If we accept it, we may note particularly the difference in verb choice: for 'son', the more emotive '̇vín $\mu$; for 'father', the more generalizing $\tau i \theta \eta \mu$.

40 Detailed discussion of the possible definitions by Cameron (n. 15), 342-5.

${ }^{41}$ E.g. R. Pfeiffer, History of Classical Scholarship from the Beginnings to the End of the Hellenistic Age (Oxford, 1968), 13: 'the new poetical school of Callimachus and his followers was ostentatiously anti-Aristotelian. Rejecting unity, completeness and magnitude, it consciously aimed at a discontinuous form.' To traditional readings of Callimachus' ěv should be added the excellent discussion by Harder (n. 2 [vol. 2]), 18-22, who argues that, whilst $\check{\varepsilon} v$ for Aristotle signified a unity of plot, and for Callimachus is probably numerical ('one single'), the Aetia phrase engages with the Aristotelian definition in that it presents a means by which the poet circumvents its charge.

42 See Cameron (n. 15), 342, who thus argues against an application of the phrase to epic.

43 I was led to 'preposterous' by P. Parker, Literary Fat Ladies. Gender, Rhetoric, Property (London, 1987) and, most pertinently, by S. Goldhill, 'Preposterous poetics and the erotics of death', Eugesta 5 (2015), 154-77.

44 In contrast to creating this structural cohesion, it should be noted that the Posthomerica maintains (and therefore continues) the other sense in which Homeric epic could be considered non-unitary-the episodic nature of the Iliad and particularly of the Odyssey, which is reinforced by the episodic nature of the Quintan poem. That it is possible to have both a unified and an episodic Homeric 'trilogy' seems to be the message here. 
Theogonic invocation (Hes. Theog. 22), where it refers more unequivocally to the art of song in general. ${ }^{45}$ Under this system of meaning, the phrase insinuates that 'all song' was originally placed in Homer's breast: $\pi \hat{\alpha} \sigma \alpha v$ underscores the notion of each and every song that he has written-the Iliad, the Odyssey, the current poem-in-themiddle - and also encompasses everything in between.

This notion is in itself no polemical rallying cry. A number of works and traditions in Late Antiquity cite Homer as the container for all subsequent cultural and intellectual production. Pseudo-Plutarch's Essay on the Life and Poetry of Homer presents the poet as $\dot{\eta} \dot{\alpha} \rho \chi \dot{\eta}$ of all things, from politics to philosophy, medicine, drama and literature. The writers of Neoplatonist allegoresis sought to reconcile the views of their two heroes by conceiving of Homer as a divine sage privy to the most fundamental forms of knowledge and truth. ${ }^{46}$ Callimachus himself, whose poetics is based on the premise that it is artistic death to attempt imitation of Homer precisely because of his insurmountable authority, would have been unperturbed by this presentation of him as figurehead of all later song. It is Quintus' combination of these claims-the two senses of $\pi \hat{\alpha} \sigma \alpha \mathrm{v}$

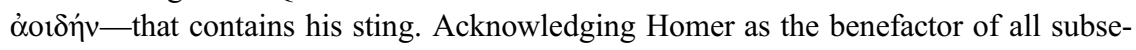
quent poetry, he does not deviate deferentially from this almighty source: rather, he mobilizes this concept into the act of writing traditional epic itself; presenting an all-encompassing vision of Homer's poetry at the same time as composing a work which claims to be continuing it. It is apposite that the very word $\alpha$ ot $\delta \dot{\eta} v$ combines all three alluded-to poets: taken from the Hesiodic proem, also found in Callimachus'

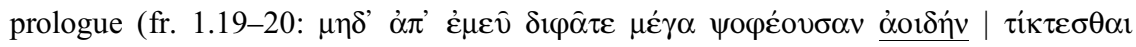
...), all encompassed into this Homeric-Quintan song.

A further hint in these lines could encourage this image of the poetic whole. The adjective $\pi \mathrm{o} \lambda v \chi \alpha v \delta \dot{n} \varsigma$ (12.307), an Alexandrian neologism, is used with unprecedented frequency in the Posthomerica, ${ }^{47}$ often to describe a huge space containing smaller composite parts: a lion's stomach crammed with prey (1.527); the coffin containing the scorched bones of Achilles (3.731); the cave housing the amassed gore of Philoctetes' seeping wound (9.390), and twice the hollow stomach of the Wooden Horse ready to be filled with heroes (also at 13.138). ${ }^{48}$ This sense of $\pi \mathrm{o} \lambda v \chi \alpha v \delta \dot{n} \varsigma$ is stressed and stretched in the present horse-description. The separateness of line 306

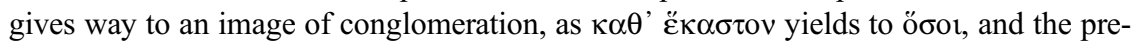
position $\kappa \alpha \tau \dot{\alpha}$, which in line 306 stressed the individuality of each hero, is redeployed as

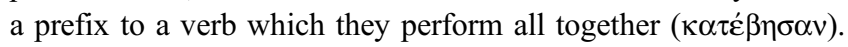

Now, $\pi \mathrm{o} \lambda v \chi \alpha v \delta \eta \dot{\zeta}$ does not have a rich metaphorical tradition: in the majority of its uses in Imperial poetry, ${ }^{49}$ and in Theocritus and Nicander, its only two Hellenistic occurrences, ${ }^{50}$ it is employed in a very literal sense, not to convey statements of poetics.

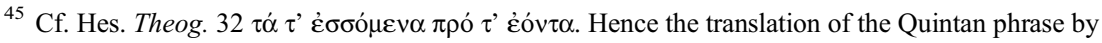
Campbell (n. 5), 103 'all song', accepted by Maciver (n. 4), 34 n. 124.

${ }^{46}$ For pseudo-Plutarch, see J. Keaney and R. Lamberton (edd.), Essay on the Life and Poetry of Homer (Plutarch) (Atlanta, 1996). For the Neoplatonist reading of Homer, see R. Lamberton, Homer the Theologian: Neoplatonist Allegorical Reading and the Growth of the Epic Tradition (Berkeley, 1986) and F. Pontani, Sguardi su Ulisse. La tradizione esegetica greca all'Odissea (Rome, 2005).

47 Cf. Bär (n. 4), 57-8.

48 Cf. the similar 'pregnant' connotations of the adjective in Oppian, Halieutica 5.331-2, describing the cavernous belly of the whale; and Triphiodorus 412 ( $\left.\delta \dot{\varepsilon} \mu \alpha \varsigma \pi \mathrm{o} \lambda v \chi \alpha \nu \delta \varepsilon \dot{\varepsilon} \circ \mathrm{i}^{i} \pi \pi \mathrm{ov}\right)$ and 536.

${ }^{49}$ See especially the discussions by E. Livrea, Nonno di Panopoli, Parafrasi del Vangelo di S. Giovanni, Canto B (Bologna, 2000), on Nonn. Par. 18.77 and by R. Franchi, Nonno di Panopoli. Parafrasi del Vangelo di S. Giovanni: Canto Sesto (Bologna, 2013), on Nonn. Par. 6.51.

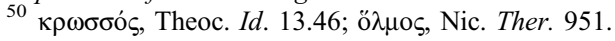


And yet, in this passage it is attached to an object which is steeped in just such a history of double meanings. The inherent duplicity of the Wooden Horse- benign offering and hidden disaster, artificial yet seemingly alive ${ }^{51}$-lends it great symbolic potency, and it often seems to stand for the art of heroic storytelling itself. When Menelaus recalls in the Odyssey how Helen circled the Horse and named each of the Greeks hiding inside, through this act Helen becomes a creative participant in the Trojan War tradition, 'describing' the Horse and moulding our judgements on the chieftains within it (Od. 4.274-8). ${ }^{52}$ By merging the usually literal $\pi \mathrm{o} \lambda v \chi \alpha v \delta \dot{n} \varsigma$ with this slippery and multidimensional Horse, Quintus may be seen to be negotiating a metaphorical reading for the term; his $\pi \mathrm{o} \lambda v \chi \alpha v \delta \eta ் \varsigma ~ i \pi \pi \circ \varsigma$ can symbolize his chosen method of (re)telling this heroic tale. ${ }^{53}$ If so, then as a picture of his poetry, the gaping stomach of the Horse to be filled with individual soldiers provides a fitting visualization of the $\pi \hat{\alpha} \sigma \alpha \dot{\alpha} o เ \delta \dot{n}$ that the Posthomerica seeks to create-one amassed work which contains within it many different aspects and influences, so that an Alexandrian neologism is made to contribute to this defence of large-scale incorporative epic.

\section{MUSES AND KNOWLEDGE}

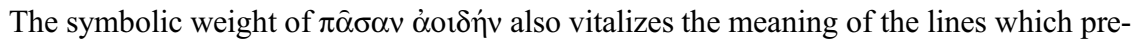
cede it: the allusion to Callimachus heightens expectation of further Callimachean allusion. In Quintus' instructions to the Muses (12.306-7), beyond the similarities to the Iliadic call ${ }^{54}$ lies a significant difference in tone; a shift of emphasis away from the Muses and their power onto the poet's own desire for knowledge and the clarity of information he wishes to receive. This deviation has been read as a nod to the Hesiodic influence on these lines. ${ }^{55}$ And yet, the infiltration of the Archaic concept of the Muses with the personal curiosity of the narrator is a notable aspect of many Imperial Muse calls. Triphiodorus' bossy demand for Calliope to hurry up (1-5) is a far cry from Homeric-Hesiodic demurral and wonder. The author of an ethopoiia dated to the third/fourth century C.E.- What Hesiod would have said when inspired by the Muses' (P.Oxy. 3537) — goes so far as to rewrite the original Hesiodic call to include such narrator-centric elements. In this composition Hesiod speaks, feels the presence of the Muse and asks her in person to inspire him with the Theogony and the Catalogues; and bidding farewell to the rustic verse and bucolic pipe-both of which were the hallowed gifts of the Muses ${ }^{56}$ - he presents himself not as humbled peasant enraptured by his inspirers but as a grand poet unfolding the facts of his own song. ${ }^{57}$

${ }^{51}$ Cf. the ecphrasis at Quint. Smyrn. 12.122-56. Triphiodorus' version of this ecphrasis (57-98) is even more playful with the competing claims of artifice and enargeia.

52 See N. Worman, 'This voice which is not one: Helen's verbal guises in Homeric epic', in A. Lardinois and L. McClure (edd.), Making Silence Speak: Women's Voices in Greek Literature and Society (Princeton, 2001), 19-37.

53 This potential thus applies to Triphiodorus too, who also uses the adjective for the Wooden Horse (412).

54 Detailed discussion of these echoes in Bär (n. 4), 41-5.

55 Campbell (n. 5), 103-4 and Bär (n. 4), 43 and 45-7.

56 As is shown in the Latin tradition; cf. Verg. Ecl. 6.69.

57 The author also resolutely refuses the Augustan recusatio at lines 25 onwards, and in its hexameter techniques shows close familiarity with Callimachean practices. 
This shift can in fact be understood as the influence of a distinctive feature of Callimachean poetics. Fragments of the dialogue which frames Aetia 1-2, though scanty, show how, in extending the single question and answer into a two-way conversation, the poem challenges the convention of the Muses as the source of all knowledge, since the goddesses encounter an eager and erudite human interlocutor who adds his own insight into the mix. ${ }^{58}$

Quintus' invocation reveals a close affinity with this Callimachean brand of curiosity. $\dot{\alpha} v \varepsilon 1 \rho \circ \mu \dot{\varepsilon} v \omega$ hints at a dialogue. The construction $\mu$ or $\dot{\alpha} v \varepsilon 1 \rho \mu \mu \dot{v} v \omega$ usually occurs during the inquiry section of a two-way exchange-to refer reflexively to the questioner who expects answers from his informant. ${ }^{59}$ That such an exchange is only faintly implied in Quintus' invocation may make a direct association with the extended conversations of the Aetia seem unlikely. And yet, such a possibility may be strengthened by the striking similarity to an epigram describing these discussions:

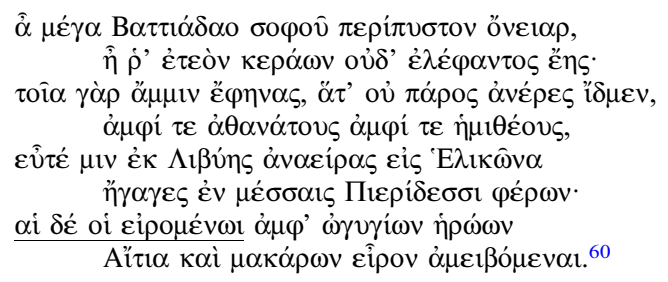

$\mathrm{O}$ great and widely known dream of the clever Battiad, truly you were of horn and not of ivory, for such things you showed us, which we men did not know before, about the immortals and about half-gods, when you lifted him up from Libya and brought him to Mt Helicon, placing him in the middle of the Pierian Muses; and they told him in answer to his questions the Aetia about the ancient heroes and blessed gods.

If, as Harder suggests, these lines owe something to Callimachus himself, ${ }^{61}$ then Quintus' phrasing may recall just such sections of the Aetia, imparting a specifically Callimachean flavour to the announcement of his request. The sense of awe at the Muses and their power is also eroded and replaced by a more 'secular' search for knowledge. The Movo $\sigma \alpha$ are deprived of any elaborating formula (such as the Iliad's 'O $\lambda \dot{v} \mu \pi 1 \alpha \delta \omega \mu \alpha \tau$ ' $\chi^{\prime} \chi 0 v \sigma \alpha \iota$ or Hesiod's laudations at the opening of the Theogony) and in the place of such Archaic complements is a strident emphasis on the manner in which they should convey their information: immediately (vv̂v), specifically ( $\kappa \alpha \theta^{\prime}$

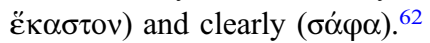

This use of Callimachus' techniques, however, refuses to be read as a reflection of his aesthetics. For Quintus embeds this confident emphasis on inquiry into the lines, which, as we have seen, most closely repeat the second Iliadic call to the Muses (Il. 2.484-7), with matching imperative ("̌ $\left.\sigma \pi \varepsilon \theta^{\prime}\right)$, immediacy (vv̂v) and catalogue-style

${ }^{58}$ Cf. e.g. fr. 7c; fr. 43.18.

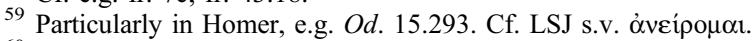

${ }^{60}$ Harder T $6=$ test. 27 et 1 , p. 11 Pfeiffer.

${ }^{61}$ Harder (n. 2 [vol. 2]), 4-5 and 93 and H. Beckby (ed.), Anthologia Graeca (Munich, 1965), vol. 2 support Pfeiffer's suggestion of a Byzantine date for the epigram. The epigram also entered The Database of Byzantine Book Epigrams (DBBE), compiled at the Universiteit Gent (http:// www.dbbe.ugent.be/type/view/id/2604/9).

${ }^{62}$ Maciver (n. 4), 34 astutely suggests that this desire for precision indicates rivalry with previous catalogues on this topic-Quintus wants this version to be the right one. 


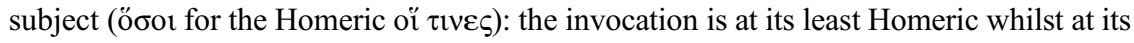
most. The Iliadic catalogue is also the site of the rare narratorial 'ego' in Homer, who famously could not name the mass of men 'even if I had ten tongues and ten mouths, an unbreakable voice and a heart of bronze' (Il. 2.488-90). So in imitating this Iliadic invocation (also thematically relevant, of course, because he is doing a catalogue of his own), Quintus echoes the moment where Homer himself comes closest to voicing a 'Hesiodic' and 'Callimachean' poetic I. As a symbol for the tradition of initiation, Quintus' call thus eradicates the divide between the Archaic and the Alexandrian approaches, taking their contrasting facets of distance and closeness, knowledge and authority, and transforming them into a composite whole.

\section{YOUTH}

Quintus then describes the timing of his inspiration, which occurred during his youth (309). Youth and childhood have long been recognized as running themes in the Aetia. ${ }^{63}$ The Telchines accuse Callimachus of writing $\pi \alpha i \varsigma$ ö $\tau \varepsilon$ (fr. 1.6), and he refutes them with the claim that 'whomsoever the Muses did not look askance at as a child they

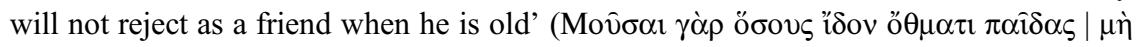

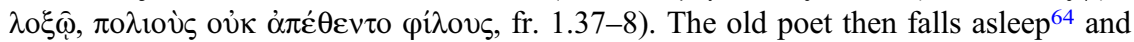
his young counterpart meets the Muses in a dream, where, a scholium relates, he is

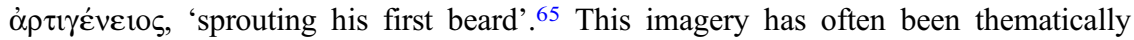
connected to Callimachus' innovating intentions in his poetry, his aim to traverse paths yet untrodden and create something fresh and new. ${ }^{66}$

In Quintus' image of down spreading on the young shepherd's cheeks, there can be little doubt of the presence of Callimachus' youthful inspiration. ${ }^{67}$ Again, however, as soon as we notice the Callimachean intensity of this line, it is simultaneously reasserted that Homer is supposedly speaking it, here through the use of a phrase distinctively Homeric in origin. In Book 11 of the Odyssey, Odysseus describes how in the underworld he saw Otus and Ephialtes, who were slain by Apollo 'before down covered

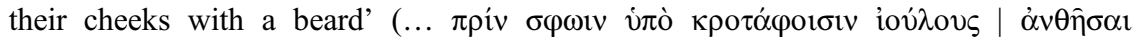

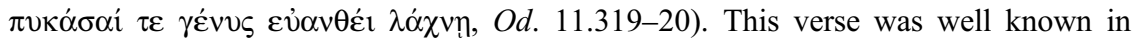
antiquity and gave rise to a host of imitations. ${ }^{68}$ By evoking it, Quintus again collides Homeric quotation and Callimachean thematics and suggestively connects the latter to

${ }^{63}$ Cf. e.g. Cameron (n. 15), 129-32.

${ }^{64}$ For this intervening narrative, see A. Kerkhecker, 'Ein Musenanruf am Anfang der Aitia des Kallimachos', ZPE 71 (1988), 16-24; A. Harder, R. Regtuit and G. Wakker (edd.), Callimachus (Hellenistica Groningana 1) (Groningen, 1993), 96; and Cameron (n. 15), 129-31.

65 fr. $2 \mathrm{~d}=\Sigma$ Flor. $15-20$. For further discussion of this adjective and its subsequent imitationsuggesting that the phrasing of the scholium may owe something to the text of Callimachus-see e.g. Cameron (n. 15), 131 and Harder (n. 2 [vol. 2]), 144. Harder's translation, however, 'while he was still a young man' (n. 2 [vol. 1], 128), does not capture the specificity of the word.

${ }^{66}$ Cf. Bär (n. 4), 48 n. 66.

${ }^{67}$ The connection has been noted: Campbell (n. 5), 104; Bär (n. 4), 48; Boyten (n. 4), 278; and K. Carvounis, 'Landscape markers and time in Quintus' Posthomerica', in M. Skempis and I. Ziogas (edd.), Geography, Topography, Landscape: Configurations of Space in Greek and Roman Epic (Berlin, 2014), 181-208, at 183. It is how Quintus uses this image that requires reconsideration.

${ }^{68}$ Examples listed by Campbell (n. 5), 104. 
Homer's poetic voice, imagined as using elements from his formulaic repertoire to describe his initial inspiration.

But Quintus does not just reclaim a Callimachean topos; he competes with his youthful reminiscence. Whereas the poet of the Aetia is old as he dreams of his inspiration, ${ }^{69}$ Homer here is no such geriatric. Although Quintus states that he was young when he received his first initiation, he does not specify how old he is now. ${ }^{70}$ This ambiguity is particularly pointed if read against the ancient tradition that the Odyssey was the work of Homer's old age, as evinced most spiritedly by pseudo-Longinus, who compares that poem to the setting sun, since it shows how, 'as great inspiration fades

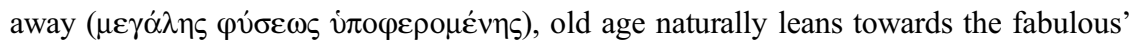
(Subl. 9.11-13)..$^{71}$ Quintus' self-portrayal as no longer young, but not specifically old, thus reflects the position of his composition in the Homeric ouvre-an active post-Iliadic pre-Odyssean middle age. His stage of beardedness is also one phase earlier

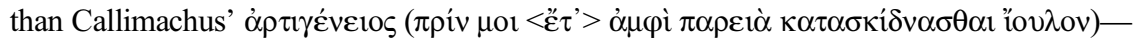
Homer gains literal as well as literary earliness. Youth is thus not merely evoked as a Callimachean nod. It is transformed into a Homeric-competitive symbol, a reminder that, in Quintus' hands, this founding source of the whole poetic tradition is also revitalized and ever new.

\section{TOPOGRAPHY AND GRANDEUR}

The final section of the proem depicts where this youthful inspiration took place (12.310-13). As we have seen, the impression of locational precision in these lines anchors the description to Homeric (auto)biography. Yet, in a passage so charged with self-consciousness, the specific place choices also have a role to play in the proem's symbolic system.

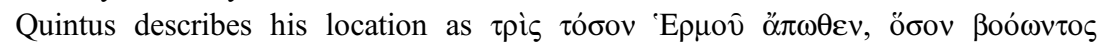

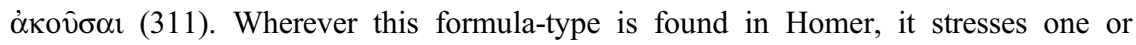
both of two points: a greatness of distance, and a loud volume and amplitude. ${ }^{72}$ Quintus activates both senses of the expression. The adverb ö $\pi \omega \theta \varepsilon v-$ not found in the Homeric examples-intensifies the sense of vast expanse. The Hermus provides another distance marker. Achilles names the river in the Iliad as he kills Iphition, citing his birthplace 'by the eddying Hermus' to emphasize sneeringly how far away from his

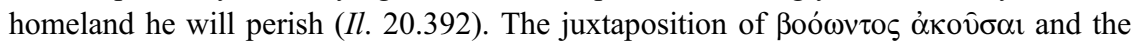
substitution of $\gamma \dot{\varepsilon} \gamma \omega v \varepsilon$ in the Homeric formula for a more explicit verb of hearing also throw simultaneous emphasis on noise and clamour.

In fr. 1.19-20 of the Aetia Callimachus advances his aesthetic statements using the imagery of noisy thunder:

${ }^{69}$ A contrast to be drawn, however, with the caution advised by Cameron (n. 15), 174-84 in his discussion of the flexibility of ancient ideas about age and ageing.

${ }^{70}$ Boyten's suggestion ([n. 4], 277) — that by implying that he is not beardless anymore Quintus insinuates that he is an old man-is not supported by the text, and neglects the possibility of this connection with Homer's supposed stages of composition.

${ }^{71}$ Translation adapted from H. Havell (ed.), Longinus On the Sublime (London and New York, 1890).

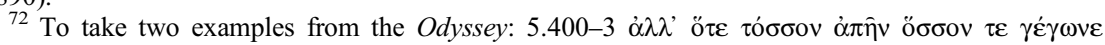

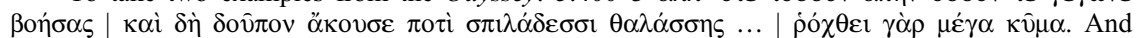

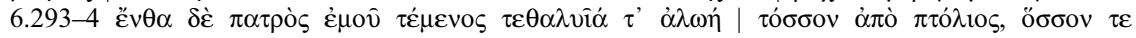

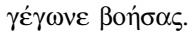




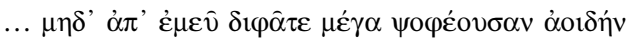

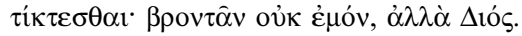

... Do not look for a loud-sounding song to be born from me; thundering is not my job but Zeus's.

In his double articulation of vastness and volume, Quintus re-harnesses this 'connection between length and bombastic style'73 in order to assert that this is precisely the type of

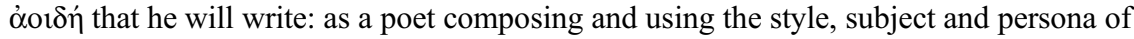
Homer, his work will be vast, and it will be loud and booming.

We then zoom in further on the inspiration-setting - near the Temple of Artemis, in the Garden of Liberty (312). ${ }^{74}$ Elsewhere in the literary tradition the garden is frequently

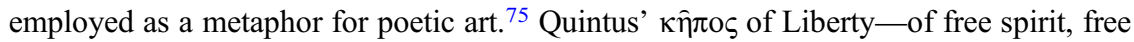
speaking or free thinking ${ }^{76}$ - builds upon this symbolic potential, serenely accommodating both the terrestrial and the lofty (by virtue of its proximity to the temple) and advocating freedom from rigidity or restraint. ${ }^{77}$ But set within these stylistic sites of size and grandeur - the noise and distance and temple — the garden asserts that for Quintus this is a freedom not to deviate from Homeric epic, but to continue it.

The hill with which the proem concludes, 'neither excessively high nor too low' (313), has already been interpreted as an aesthetic comment. Neil Hopkinson has taken it as a programmatic reference to the middle style of the Posthomerica within the genera dicendi. ${ }^{78}$ It has, however, been countered that the type of traditional heroic epic that Quintus is writing belongs by nature to the genus grande, precluding a reading of humble self-depreciation. ${ }^{79}$ If, however, we read this symbolism within the poem's framing conceit, its claims become more reconcilable. If the hill is a comment on poetic style, then it is a comment on Homer's poetic style, which Quintus seeks to take up.

In ancient discussions of poetic aesthetics, the concept of the middle style was often evoked in relation to Homer's mode of expression. Quintilian pits the Homeric stylewhich represents a model for language, characterization, organization and speech techniques-against that of Hesiod, who by contrast is a model for the middle style, with 'a well-structured composition and sweetness of sententiae; like a gentle river translucent but shaded on both sides by verdant river banks' (Inst. 12.10.60). ${ }^{80}$ Dionysius of Halicarnassus also contrasts Homer to Hesiod in stylistic terms; but for him, it is Homer who is crowned with holding the middle or 'mixed' ground

${ }^{73}$ Harder (n. 2 [vol. 2]), 53-4 demonstrates how Callimachus evokes the literary-critical connotations of $\psi o ́ \varphi \circ \varsigma$, and makes $\mu \varepsilon \dot{\gamma} \alpha$ mean both 'loudly' and echo the $\mu \varepsilon \gamma \alpha \dot{\alpha} \lambda \eta \gamma v v \eta$ of fr. 1.12.

${ }^{74}$ Many attempts have been made to identify these features geographically. See Vian (n. 2), x and

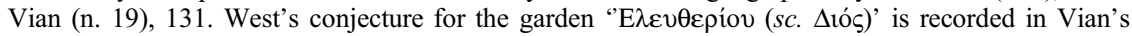
apparatus (n. 2) and discussed by Carvounis (n. 67), 182 n. 11. Such speculation has proven inconclusive, encouraging a reading based on their metaphorical rather than on factual interpretative function.

${ }^{75}$ E.g. Pind. Ol. 9.27; P1. Ion 534a.

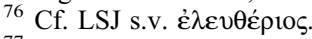

${ }^{77}$ Bär (n. 4), 61 also considers the garden as a symbol for poetic art but not in relation to Quintus' Homeric imitation.

${ }^{78}$ N. Hopkinson (ed.), Greek Poetry of the Imperial Period. An Anthology (Cambridge, 1994), 106. Related discussion by Bär (n. 4), 59-61 and Maciver (n. 4), 36.

79 James (n. 2), xviii.

${ }^{80}$ Translation from H. Butler (ed.), The Institutio Oratoria of Quintilian (London, 1921). 


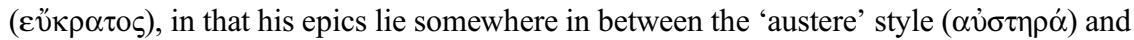
the 'smooth' style ( $\gamma \lambda \alpha \varphi v \rho \grave{\alpha} \sigma u ́ v \theta \varepsilon \sigma 1 \varsigma)$ modelled by Hesiod (Comp. 23.2-7). ${ }^{81}$

Quintus' portrait of the hill has much in common with these rhetorical configurations. He shares in the metaphorical language of Quintilian, in which a feature of nature functions as an image of style. And by crowning this style neither excessively high nor low, he concurs with Dionysius that Homer occupies the privileged middle ground. But whilst these treatises pit Homer against the aesthetic traditions which came after him, Homer's style as presented by Quintus avoids such diachronic dichotomies. Not conforming to a rigid set of criteria, it blends within it a number of different partsincluding the Hesiodic, and even the Alexandrian-perfectly represented by a hill which defies precise categorization. ${ }^{82}$

Whilst Ű oऽ was a common metaphor for the grand style in antiquity, ${ }^{83} \chi \theta \alpha \mu \alpha \lambda$ ó $\varsigma$ was not its usual conceptual antithesis. ${ }^{84}$ Why then should Quintus use it, forfeiting the more recognizable doublet? ${ }^{85}$ The answer may lie in the frequent associations of $\chi \theta \alpha \mu \alpha \lambda$ ó $\varsigma$ in the Odyssey with Ithaca. ${ }^{86}$ When Odysseus describes his homeland to the Phaeacians, the adjective creates a difficult juxtaposition (Od. 9.25-6):

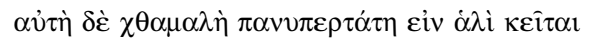

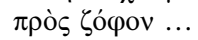

Ithaca itself lies low in the sea, highest of all towards the dark ...

Ithaca's simultaneous status as $\chi \theta \alpha \mu \alpha \lambda \eta \dot{~ a n d ~} \pi \alpha v v \pi \varepsilon \rho \tau \alpha \dot{\tau} \tau \eta$ perplexed ancient commentators. ${ }^{87}$ Employing the word in his own description of a space that is at once high and low, Quintus could be inviting an association with the simultaneous height and lowliness of Ithaca-and, by transferal, the stylistic highs and lows within

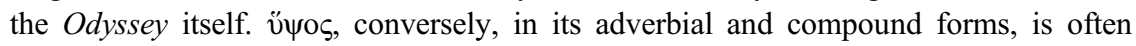
used in the Iliad to describe that epic's spatial setting and subject matter: the lofty towers of Troy and the fighting that takes place beneath them. ${ }^{88}$ It is a word connected to Iliadic heights. Read against these precedents, Quintus' doublet allows the literal, thematic and

${ }^{81}$ Translation adapted from W. Roberts (ed.), Dionysius of Halicarnassus on Literary Composition (London, 1910). As Hunter notes, this category has much in common with Quintilian's version of the 'middle style' (see R. Hunter, Hesiodic Voices. Studies in the Ancient Reception of Hesiod's Works and Days [Cambridge, 2014], 286).

${ }^{82}$ In contrast to the specificity of the rest of the proem, the hill's lack of name and its pin-pointed location heighten its ability to stand for something which precludes rigid compartmentalization.

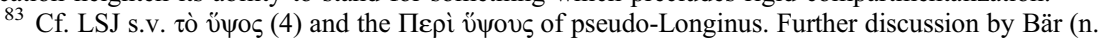
4), 59.

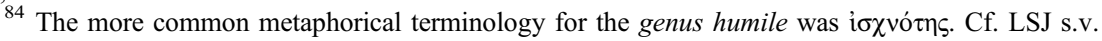

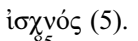

${ }_{85}$ Bär's suggestion ([n. 4], 59 n. 122) that with $\chi \theta \alpha \mu \alpha \lambda$ ó $\varsigma$ Quintus aims at a translation of the Latin humilis is possible, but would be an unusual move for Quintus; and it seems less likely to me than Quintus' interaction with the Odyssean connotations of the word, and at any rate does not preclude it.

${ }^{86}$ Cf. Od. 10.96; Strabo 10.2.12.

${ }^{87}$ Cf. $\Sigma O d$. ad loc., which asks ' $\pi \hat{\omega} \varsigma \chi \theta \alpha \mu \alpha \lambda \eta \dot{\eta} ; \pi \hat{\omega} \varsigma \pi \alpha v v \pi \varepsilon \rho \tau \dot{\alpha} \tau \eta$;' and lists various attempts to reconcile the two concepts. For the persistence of this uncertainty, cf. LSJ s.v. $\chi \theta \alpha \mu \alpha \lambda$ ó $\varsigma$ (2).

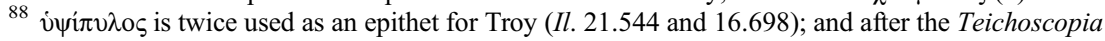
Aphrodite finds Helen $\pi \dot{\rho} \rho \gamma \omega \dot{\varepsilon} \varphi \varphi^{\prime} \dot{v} \psi \eta \lambda \hat{\omega}$ (Il. 3.384). The related adverbs ü $\psi \mathrm{r}$ and $\dot{v} \psi \mathrm{v}$ are most frequently employed in the Iliad to describe battle tactics, positions or situations: the striking of a blow (e.g. Il. 13.140), the mooring of Achaean ships (Il. 1.486; Il. 14.77), a dust cloud rising from the battlefield (Il. 16.374) or the Achaeans lifting the corpse of Patroclus (Il. 17.723). 
stylistic possibilities of the words to combine into a reading of the Homeric canon itself. Subtly evoking both its highs and its lows, he thereby suggests the inaccuracy of attributing any excessive loftiness to the Homeric epics, even as he is still composing them.

$\dot{v} \psi o ́ \theta t$ is also frequently applied in poetry to Zeus and the gods, as in the Homeric

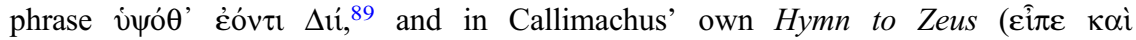

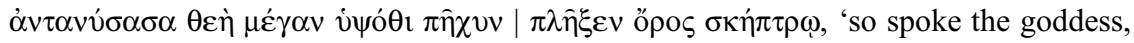
and lifting her great arm aloft $\mid$ she struck the mountain with her staff [30-1])..$^{90}$ If, by leaving thundering to Zeus, Callimachus links his rejection of the high, grand style to a prudent avoidance of hubris, then by juxtaposing such loftiness with tokens of Homeric lowliness, Quintus removes the sting of such an association. Homeric epic itself, as Quintus reads and presents it, successfully incorporates both the high and the low; and thus to imitate or, better still, to continue this epic is not an arrogant attempt at greatness but the logical harnessing of a style which will always best encapsulate the middle way.

\section{TENDING FAMOUS SHEEP}

In our final self-reflexive marker, set within these topographical details, Quintus describes his former self as tending $\pi \varepsilon \rho ı \kappa \lambda \nu \tau \dot{\alpha} \mu \hat{\eta} \lambda \alpha$ (310). Through its double allusion to Hesiod's Theogony and Callimachus' Hesiod in the Somnium, this phrase more than any other in the proem marks out its intertextuality. Calum Maciver has shown how the adjective $\kappa \lambda \nu \tau \alpha$, which has a double meaning 'excellent/of quality' and 'famous/ renowned', ${ }^{91}$ is elsewhere used by Quintus to comment on his poetry and its place in the chain of literary forerunners, a 'footnote' suggesting the sort of subtle and learned use of his models akin to the Alexandrian poets. ${ }^{92}$ The proem's $\pi \varepsilon \rho \iota \kappa \lambda \nu \tau \alpha$ replays this significance on a more intensive level, pointing to a perceived superiority in comparison:

The shepherd of the passage has sheep which are of superior quality to other sheep. Quintus' poetry is of eminently superior quality to other poetry, and, by implication, the poetry of the three he embeds in this passage: Homer, Hesiod and Callimachus. ${ }^{93}$

However, another flock of sheep-of $\kappa \lambda \nu \tau \grave{\alpha} \mu \hat{\eta} \lambda \alpha-$ neglected in Maciver's discussion significantly affects the symbolism of this image. During his Apologoi, Odysseus describes the rams of Polyphemus under whose fleeces he and his crew make their escape (Od. 9.307-9):

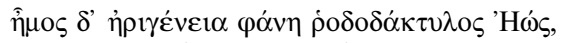

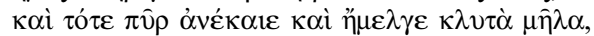

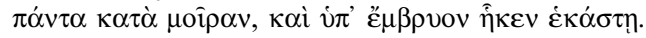

As soon as early Dawn appeared, the rosy-fingered, he rekindled the fire and milked his fine flocks all in turn, and beneath each dam placed her young.

${ }^{89}$ E.g. Il. 10.16.

90 Translation adapted from A. Mair, Callimachus: Hymns and Epigrams. Lycophron (London, $\left.1955^{2}\right)$.

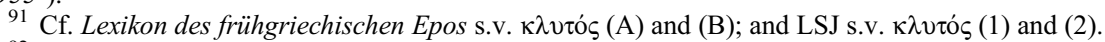

92 Maciver (n. 4), 35-8 and Maciver (n. 7), 54-5 and 66.

93 Maciver (n. 4), 37. 
It is generally considered that of the two possible meanings of $\kappa \lambda v \tau$ ó the former is being employed here: the Cyclops' sheep are splendid and fine-looking in appearance, a miniature focalization of Polyphemus' admiration for them. ${ }^{94}$ And yet, this visual sense of the adjective is usually restricted in Homer to inanimate objects like armour or houses; ${ }^{95}$ and nowhere else is $\kappa \lambda \nu \tau \alpha$ used of animals except here. ${ }^{96}$ This all suggests that 'fine-looking' is only part of the meaning in Odysseus' words.

Polyphemus is surrounded by his sheep during his daily routine, and is particularly fond of his large ram, to whom he will later affectionately speak, unaware that Odysseus is hiding beneath (Od. 9.447-60). The sheep are thus 'fine' at Od. 9.308 from an internal perspective, but they are famous from an external one, thanks to their role in the very adventure being narrated; their true significance unfolds as the tale progresses, revealed in the spectacular exit. Odysseus thus mobilizes the second meaning of the polyvalent $\kappa \lambda v \tau \alpha \dot{\alpha}$ as a nod to his retroactive self-awareness as a narrator, an ironic marker of his privileged knowledge and position as the teller of this epic tale. ${ }^{97}$

This doubleness of the Odyssey's sheep has important implications for Quintus' allusion. Referring to an Odyssean episode so centred on identity, anonymity and self-

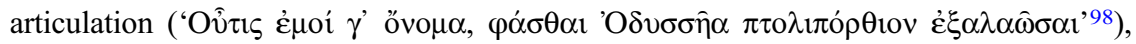
Quintus' phrase does indeed inscribe his own poetics of naming, defining his epic voice in light of its literary predecessors. But by taking up Odysseus' expression, and by harnessing its ironic double meaning, he acknowledges the fame of the poetry he is writing from a Homeric perspective. In a dizzying proleptic game, Quintus' sheep are actually Homer's sheep: they are the sheep in the Odyssey which, within the conceit of the poem, has not yet been written, and they are described in the same way as Homer's most double-speaking character will 'later' depict them. By transference, as a symbol for his poetry, these sheep are very famous not because Quintus has improved on Homeric epic, but because he is imitating it. The subsequent poetic traditions acknowledged by the intertextuality of this line are not evoked to diminish the importance of the Homeric original. Rather, Quintus employs the same retroactive foresight as Odysseus to write them into this superlative fame. It is thanks to the efforts of these later poets that Homer's 'sheep' (his poetry) have been able to become $\kappa \lambda v \tau \dot{\alpha}$, even $\pi \varepsilon \rho \iota \kappa \lambda \nu \tau \dot{\alpha} .{ }^{99}$ And by the act of continuing this poetry Quintus himself is now able to tend this most celebrated flock. Posing as Homer grants him access to material of the highest quality and renown.

94 Cf. the translations by Campbell (n. 5), 104 'of outstanding quality', and Murray (n. 2) 'goodly'.

95 References collated by Maciver (n. 7), 54 n. 6.

96 When Maciver ([n. 7], 54) states that 'nowhere in either Homer or Quintus is $\kappa \lambda v \tau \dot{\alpha}$ used of animals or insects, except at Quint. Smyrn. 6.324 [ $\left.\mu \varepsilon \lambda \_\sigma \sigma \alpha \omega \nu ~ \kappa \lambda \nu \tau \dot{\alpha} \varphi \hat{v} \lambda \alpha\right]$ ', he omits this important instance.

${ }_{97} \kappa \lambda v \tau$ ó $\varsigma$ is frequently used in the Odyssey as an epithet of a bard: cf. 1.325, 8.83, 8.367 and 8.521 (so Bär [n. 4], 51), strengthening the possibility that its use here is indicative of Odysseus' status as internal teller of this tale.

${ }^{9} \mathrm{Od}$. 9.366 and 9.504 .

99 The prefix $\pi \varepsilon \rho \mathrm{-}$, which may have been selected by the poet for more metrical reasons than Maciver suggests, could none the less also carry connotations of a 'perceived superiority' in this spectrum of poets, as he suggests; but what is crucial is that the superiority belongs to Homer, it is not set against him. 


\section{CODA: DECLASSIFYING QUINTUS}

In these duplicitous sheep, we find encapsulated the approach to Alexandrian poetics in the proem's encoded statements. Claiming-or, better, reclaiming-the retrojecting anachronistic moves so typical of Alexandrian poetry for Homeric epic, Quintus adopts the games of Callimachus to validate the Homeric poetics of his undertaking: his own literary game. The Posthomerica thus establishes its Homeric-ness both against, but also by means of, Alexandrian, Callimachean, poetics.

I began by suggesting that the proem functions as a map for the imitative strategies of the poem. The next step will be now to use this map, and to apply its directions to the other elements of the Posthomerica: the formulaic switches, the source combinations, the range of narrative and literary interactions, which are still too often polarized in discussions of this author, read as either Homeric or un-Homeric, Alexandrian or non-Alexandrian, in the persistent desire to categorize Quintus. The programmatic system of the in-proem, as this article has understood it, provides perhaps the strongest ammunition to rethink this current mode of rethinking. Acutely aware of the literary manoeuvres available to him and the innovative pressures of his time, Quintus advocates an alternative answer to charges of bland imitation, which declares the value of a poetic endeavour not in terms of deviation from traditional epic but through explicit dependence upon it. Confronting his Homeric affiliation proudly and without apology, he finds a way to redefine it as a discrete epic agenda-a post post-Homeric poetics, in which the polarizing statements of the Aetia become the new Telchines, against whose charges the voices of Homer and Hesiod and Callimachus can chime in the polyphony of the Quintan song.

University of Cambridge

EMMA GREENSMITH eg357@cam.ac.uk 